\title{
Çocuklardaki Alerjik Rinit, Astım ve Atopik Dermatitle Adipokinlerin İlişkisi
}

\author{
Associattons of Adipokines with Allergic Rhinitis, Asthma and Atopic \\ Dermatitis in Children
}

\author{
${ }^{1}$ Fatma Aydın, ${ }^{2}$ Hülya Anıl, ${ }^{2}$ Abdülkadir Koçak, ${ }^{2}$ Koray Harmancı, ${ }^{1}$ Gürkan Bozan \\ ${ }^{1}$ Clinic of Pediatrics, Osmangazi University Medical Faculty, Eskisehir, Turkey \\ ${ }^{2}$ Pediatric Allergy and Immunology Department, Osmangazi University Medical Faculty, Eskisehir,
}

Turkey

\begin{abstract}
Özet: Adipokinler ile alerjik hastalıklar arasında giderek artan oranda bir ilişki saptanmasına rağmen, altta yatan mekanizmalar hakkında elimizde çok az veri bulunmaktadır. Bu çalışmada plazma leptin ve adiponektin konsantrasyonlarının astım ve diğer alerjik hastalıklarla olan ilişkisinin incelenmesi amaçlanmıştır. Astım, alerjik rinit ve atopik dermatitli 71 hasta ve 54 sağlam çocuk çalışmaya alınmıştır. Vücut kitle indeksleri, solunum fonksiyon testleri ve deri prick testleri yapilan hastalardan total eozinofil sayıs1, total serum Immunglobulin E, spesifik Immunglobulin E (phadiotop), leptin ve adiponektin düzeyleri için kan alınmıştır. Plazma leptin konsantrasyonu ile vücut kitle indeksi arasında pozitif korelasyon saptanırken, plazma adiponektin düzeyleri ile vücut kitle indeksi arasında negatif korelasyon saptanmıştır. Atopik dermatitli çocuklar diğer hasta ve sağlıklı çocuklara göre daha yüksek leptin düzeylerine sahiplerdi. Fakat adiponektin düzeyleri açısından böyle bir yüksekliğe rastlanmadı. Serum leptin düzeyleri ile vücut kitle indeksi arasında güçlü bir pozitif korelasyon saptandı. Bu sonuçlara göre serum leptin düzeyleri çocuklarda atopik dermatit riskiyle ilişkilendirilebilirken, adiponektin düzeyleriyle böyle bir ilişki saptanmamışır.
\end{abstract}

Anahtar Kelimeler: astım, leptin, adiponektin, alerjik rinit, atopik dermatit

Aydın F, Anı1 H, Koçak A, Harmancı K. 2018, Çocuklardaki Alerjik Rinit, Astım ve Atopik Dermatitle Adipokinlerin İlişkisi, Osmangazi Journal of Medicine , 40 (2):1-5 Doi: 10.20515/otd.323807

\begin{abstract}
There is growing evidence for an association between adipokines and allergic disorders but little is known about the underlying mechanisms. We hypothesized that high plasma leptin and adiponectin concentrations might be related to asthma and the other allergic diseases. We studied 71 children with allergic diseases (asthma, allergic rhinitis, atopic dermatitis) and 54 healthy children. Body mass indexes, pulmonary function tests and skin prick test were performed. Total eosinophil count, total serum immunoglobulin E (IgE), serum spesific IgE (phadiotop) leptin and adiponectin were measured in all subjects. There was a strong positive correlation for plasma leptin concentrations with body mass index BMI, Adiponectin, however, was negatively correlated with BMI. Children with atopic dermatitis had higher leptin levels compared with the other allergic diseases and control groups, but adiponectin did not show any difference among these three groups. Serum leptin levels are strongly correlated with measures of BMI. These results suggest that leptin may contribute to increased atopic dermatitis risk in children. but no correlation was found with plasma adiponectin concentrations
\end{abstract}

Key words: asthma, leptin, adiponectin, allergic rhinitis, atopic dermatitis

Aydin F, Anil H, Kocak A, Harmanci K. 2018, Associatıons of Adipokines with Allergic Rhinitis, Asthma and Atopic Dermatitis in Children, Osmangazi Tip Dergisi, 40 (2):1-5 Doi: 10.20515/otd.323807

Kabul Tarihi / Accepted: 27.02.2018
Yazışma Adresi / Correspondence Address

Hülya ANIL

mail: hulyaanil26@gmail.com 


\section{Giriş}

Astım, alerjik rinit ve atopik dermatit çocukluk çağının majör allerjik hastalıklarıdır ve birliktelikleri gözlenmektedir $(1,2)$. Epidemiyolojik çalışmalar astım ve obezite prevalansının birlikte arttığını göstermektedir (3). Sedanter yaşam şekli,diyet faktörü,sistemik inflamasyon, obeziteyle beraber azalmış göğüs duvarı kompliyansı, insülin direnci, komorbiditeler ve ortak genetik yatkınlığa bağlı bir ilişki olabilir. Obezite ilişkili yağ doku kaynaklı leptin ve adiponektin gibi adipokinlerin immun fonksiyonlar üzerine yaptığı değişiklikler diğer olası mekanizmalardır (4-8).

Obezlerdeki yağ dokusu TNF- $\alpha$, IL-6 ve Creaktif protein (CRP) gibi artmış proinflamatuvar proteinlerden sorumludur. $\mathrm{Bu}$ sitokinler solunum yolu inflamasyonunda, artmış solunum yolu kontraksiyonunda ve glukokortikoid yanıtında rol oynayabilir (9). Bir adipokin olan leptin yağ dokusu artışı ile artar ve proinflamatuvar etkileri vardır (10). Bunun aksine adiponektin yă dokusu artışı ile azalır ve antiinflamatuvar özellik gösterir (11).

Leptinin proinflamatuvar ve adiponektinin antiinflamatuvar birer mediatör olmalarından yola çıkarak plazma leptin ve adiponektin konsantrasyonları çocuklarda astım ve diğer allerjik hastalıkların etyopatogenezinde rol oynayabilir. Serum adipokin seviyelerinin astım ve obezite birlikteliğindeki etkisine yönelik yapılmış çok sayıda çalışma bulunmakla birlikte, adipokinlerin diğer allerjik hastalıklar ve atopi parametreleri ile birlikteliğine ilişkin çalışma sayısı sınırlı kalmıştır. Bu çalışma ile astım, atopik dermatit ve alerjik riniti olan hastalarda adipokin seviyelerinin atopi parametreleri ile korelasyonunun değerlendirilmesi planlanmıştır.

\section{Gereç-Yöntem}

Eskisehir Osmangazi Üniversitesi Tip Fakültesi Pediatrik Allerji ve İmmünoloji Polikliniğine başvuran yaşları 8 ay-17 yaş arasında değişen allerjik hastalığı olan 30 erkek, 41 kız ile aynı yaş grubundan 9 kız, 8 erkek 17 sağlıklı çocuk olmak üzere toplam 88 çocuk çalışmaya alındı. Çalışmaya alınan hastaların 13'ü astım, 24 'ü allerjik rinit, 21 'i astım ve alerjik rinit, 13'ü atopik dermatit tanısı ile takip edilmekte olan hastalardı ve üst solunum yolu enfeksiyonu, tonsillit, otit, akciğer enfeksiyonu, parazitoz saptanan, ateş yüksekliği olan çocuklar çalışmaya alınmad1.

Çocukların vücut kitle indeksleri hesapland1, deri prick testi yapıldı ve 6 yaş üzerindeki hastalara solunum fonksiyon testi (SFT) yapıldı. Başvuruda alınan venöz kan örneklerinden, tam kan sayımı, serum total IgE, phadiotop inhalen ve infant çalışıldı. Serum adiponektin ve leptin düzeyi için venöz kan örnekleri antikoagülan içermeyen santrifüj tüplerine alındı ve ELISA yöntemiyle çalışıldı. Serum Leptin düzeyi 'Diasource LeptinEASIA kitiyle (Belgium)" çalışıldı ve birimi ng/ml olarak alındı. Serum adiponektin düzeyi " Biovendor ELİSA kitiyle (Germany)" çalışıldı ve birimi $\mu \mathrm{g} / \mathrm{mL}$ olarak alındı. Çalışma için Osmangazi Üniversitesi Tıp Fakültesi'nden etik kurul onayı alındı.

\section{Istatistiksel Analiz}

Verilerin istatistiksel olarak degerlendirilmesinde SPSS for Windows paket program (SPSS Inc.,Chicago, IL) kullanıldı. Değişkenlerin normal dağılıma uyumları Shapiro-Wilks ve KolmogorovSmirnov testi ile araştırıldı. Adiponektin ve leptin değerleri normal dağılıma uymuyordu. Veriler ortalama \pm SD olarak gösterildi. Karşılaştırmalar için PairedSamples T testi ve Mann Whitney U testi kullanıldı. Değiskenler arasındaki korelasyon değerlendirmelerinde: normal dağılıma uyan değişkenler için Pearson korelasyon testi, normal dağılıma uymayan değişkenler için Spearman korelasyon testi uygulandi. $\mathrm{P}<0.05$ değeri istatistiksel olarak anlamlı kabul edildi. 


\section{Bulgular}

Çalışmaya 13 astım, 24 allerjik rinit, 21 astım ve allerjik rinit, 13 atopik dermatit tanısı alan 71 hasta alındı. Hastaların 41'i (\%58) kız, 30 'u (\%42) erkek idi. Yaşları 8 ay ile 17 yaş arasında değişmekte olup ortalama yaş $8 \pm 4$ y1 idi. Hastaların ve kontrol grubunun adiponektin ve leptin değerleri arasında istatistiksel olarak anlamlı bir fark bulunmadı ( $p>0.05)$.
Serum leptin değeri gruplar arasında karşılaştırıldığında atopik dermatitli hasta grubu ile kontrol grubu arasında anlamlı düzeyde fark saptand $1(\mathrm{p}<0.05)$.

Adiponektin ve leptin değerlerinin VKİ ile korelasyonlarına bakıldığında adiponektin ile negatif $(p=0.003)$, leptin ile pozitif $(p<0.001)$ yönde anlamlı bir korelasyon bulundu (Şekil $1-2)$.

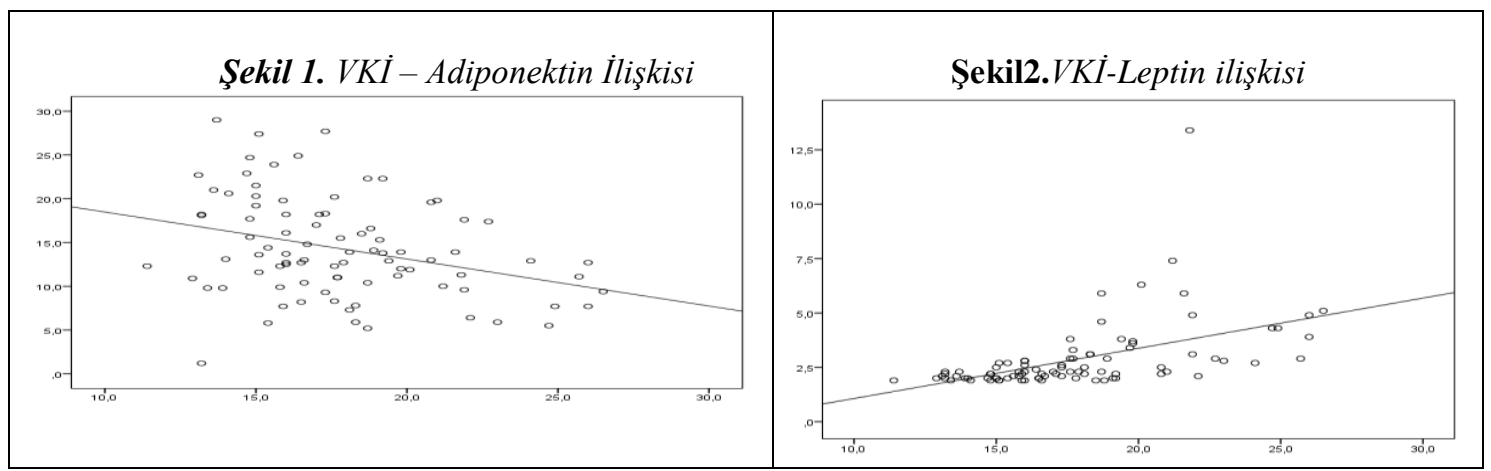

Adiponektin ve leptin değerlerinin yaş ile ilişkisi karşılaştırıldığında adiponektin ve yaş arasinda negatif anlamlı $(\mathrm{p}<0.001)$, leptin ile yaş arasında pozitif anlamlı $(\mathrm{p}<0.001)$ bir ilişki saptandı.

Adiponektin ve leptin değerlerinin serum total Ig $\mathrm{E}$ ile korelasyonu değerlendirildiğinde astımlı hasta grubunda adiponektin ile Ig E arasında istatistiksel olarak anlamlı $(\mathrm{p}=0.044)$ pozitif bir ilişki bulundu.Diğer gruplarda anlamlı bir ilişki saptanmadı.

SFT parametrelerinin adiponektin ve leptin ile ilişkisi değerlendirildiğinde adiponektin ile FEV1 arasında istatistiksel olarak anlamlı negatif korelasyon bulundu $(\mathrm{p}=0.048)$ (Tablo 1)

Tablo 1.

Adipokinlerin solunum fonksiyon testi parametreleri ile korelasyonu

\begin{tabular}{lcccc}
\hline & FVC $(\%)$ & FEV1(\%) & FEV1/FVC & PEF $(\%)$ \\
\hline Adiponektin & & & & \\
r & 0,237 & $-0,311$ & $-0,169$ & $-0,137$ \\
p & 0,135 & 0,048 & 0,290 & 0,392 \\
Leptin & & & & \\
r & 0,149 & 0,093 & 0,138 & $-0,131$ \\
p & 0,352 & 0,562 & 0,389 & 0,414
\end{tabular}

\section{Tartışma}

Çalışmamızda gruplar arası VKI korelasyonunda istatistiksel olarak anlamlı bir fark bulunmadı. Yani astımlı ve astım ile alerjik rinitin birlikte bulunduğu grup ile diğer gruplar arasında fark yoktu. 12-20 yaş aras1 368 adolesan ile yapılan bir çalışmada ise yüksek VKİ'nin kızlarda günlük artmış semptomlar ve ataklarla ilişkili olduğu 
gösterilmiştir (12). Jartti ve ark.(13) yaptığ 1 çalışmada 24-39 yaş arası grupta astım ile VKİ arasında anlamlı bir ilişki saptanmıştır, 3-18 yaş ve 9-24 yaş arası grupta bir ilişki bulunmamıştır ve astımın erişkinlerde obezite ile ilişkili olabileceği sonucuna varılmıştır. Astım ile obezite arasında doğrudan bir ilişki saptanmamakla beraber obezitenin daha çok hastalığın klinik seyri ve semptomları üzerine etkili olabileceği sonucuna varılmıştır.

Çalışmamızda serum leptin ve adiponektin değerlerinin VKİ ile ilişkisine bakıldığında leptinle pozitif $(\mathrm{p}<0.001)$, adiponektin ile negatif $(p=0.03)$ bir korelasyon olduğu görüldü.. Çalışmamızda gruplar arasındaki leptin düzeyleri karşılaştırıldığında atopik dermatitli grup ile kontrol grubu arasinda anlamlı fark saptand1. Astımlı grup kontrol grubu ile karşılaştırıldığında ise istatistiksel olarak anlamsız fakat diğer gruplara göre anlamlı bir fark bulundu. Önceki bazı çalışmalarda yüksek plazma leptin seviyelerinin artmış astım prevalansı ile ilişkili olabileceği gösterilmiştir $(14,15)$. Bizim çalışmamızda kız ve erkek hastalar arasındaki leptin düzeylerinde farkl111k görülmedi.

Bizim çalı̧̧mamızda da astım ve allerjik rinit gruplarında yüksek serum leptin düzeyi yoktu fakat önceki çalışmalardan farklı olarak atopik dermatitli hasta grubunda serum leptin düzeyleri kontrol grubuna göre istatistiksel olarak farkl11ı gösteriyordu. Atopik dermatitli hasta grubunun VKİ diğer gruplardan farklı değildi yani vücut yağ oranının leptin üretimini artırması ile ilişkili bir sonuç değildi. Bunun yanında atopik dermatitli hasta grubunun yaş ortalaması diğer gruplara göre daha küçüktü fakat leptin ile yaş ilișkisine bakıldığında yaș ile birlikte leptinin de artış gösterdiği yani yaş ile leptin arasında pozitif korelasyon olduğu görülmüştür. Atopik dermatitli hasta grubunda k1z oranı diğer gruplara daha yüksektir. Çalışmamızda yüksek leptin düzeyleri ile astım ve allerjik rinit arasında aşikar bir ilişki gösterilmedi. Leptin hem allerjik duyarlılığ artırmakta hem de allerjik olaylarla artmaktadır. Bizim çalışmamız bu hipotezi yalnızca atopik dermatit grubu için destekler niteliktedir.
Çalışmamızda leptinin atopi markerlarıyla yani kan eozinofil yüzdesi, Ig E düzeyi, phadiotop inhalen, phadiotop infant, cilt testi ve SFT parametreleri ile bir ilişkisi bulunmadi. allerjik hastalarda bizim çalışmamızda dahil olmak üzere leptin ile eozinofil arasinda anlamlı bir korelasyon görülmemiştir.

Gruplar arasında adiponektin düzeyleri karş1laştırıldığında istatistiksel olarak anlamlı bir fark saptanmadi. Adiponektinin antiinflamatuvar etkisi ile interferon-gama üretimini baskıladığ 1 ve interferon-gama artışının allerjik hastalık gelişimi için risk oluşturduğu bilinmektedir. Azalmış adiponektin ile artmış interferon-gamanın bu infantlarda artmış hava yolu duyarlılığına yol açabileceği düşünülmüştür (16). Yapılan çalışmalarda adiponektin ve allerjik hastalıklar arasında doğrudan bir ilişki gösterilememiştir. Bizim çalışmamızda da astım ile birlikte diğer allerjik hastalıklarda adiponektin ile direk bir bağlantı bulunmamıştır.

Atopi markerları ile adiponektin ilşkisine bakıldığında astımlı hasta grubunda adiponektin ile $\operatorname{IgE}$ arasında pozitif bir korelasyon bulundu. $\mathrm{Bu}$ durumun adiponektinin $\mathrm{TH} 2$ sitokin ekspresyonunu inhibe etmesi ve inflamasyona eozinofillerin katılmasinı engellemesi ile ilişkili olabileceği düşünülmüştü. Farelerle yapılan bir çalışmada adiponektin verilen grup salin verilen grupla karşılaştırıldığında ovalbümin maruziyeti sonrasi bronkoalveoler lavuj sivisinda eozinofiller adiponektin verilen grupta belirgin azalmıştı. Yine aynı çalışmada adiponektin verilen grupta ovalbumin maruziyeti sonras1 serum Ig E düzeylerinde artış olmamıştı fakat aerosol maruziyetine bakılmaksızın değerlendirildiğinde adiponektin verilen grupta Ig E seviyeleri salin verilen gruba göre daha yüksekti (17). Bizim çalışmamız da bu sonucu destekler niteliktedir.

SFT parametreleri ile adiponektin arasındaki ilişkiye bakıldığında FEV 1 ile adiponektin arasında negatif bir korelasyon olduğu görüldü. Adiponektinin bilinen en 
temel rolü antiinflamatuvar etkinliğidir fakat bizim çalışmamızda FEV1 ile adiponektin arasında bulunan negatif ve serum Ig E düzeyleri ile adiponektin arasındaki pozitif korelasyon proinflamatuvar bir etkiyi göstermektedir. Adiponektinin proinflamatuvar etkilerinin olduğu da bildirilmiştir (18). Farklı yapıdaki adiponektinin inflamasyon ve immün sistem üzerindeki etkileri net olarak bilinmemektedir.

Adiponektin ile allerjik hastalıkların doğrudan bir ilişkisi olmadığı düşünülürse adiponektin ile pulmoner enfeksiyonlar arasında kapalı bir ilişki olduğu kabul edilebilir. Adiponektinin antiinflamatuar etkileri havayolu inflamasyonunu etkileyerek akciğer fizyolojisini değiștirebilir. FEV1 bir akciğer volüm indeksidir, astım ciddiyetinin ölçümünde kullanılır ve sadece inflamasyon veya semptomlardan etkilenmez, bir çok faktörden etkilenebileceği unutulmamalıdır (14). Çalışmamızda leptinin yaş ile pozitif, adiponektinin yaş ile negatif korelasyon gösterdiği görüldü.

\section{Sonuç}

Adipokinlerin çocukluk çağında yaş ile zayıf bir ilişkisi olduğu, puberteye göre değişiklik gösterebilecekleri, puberte başlangıcında kılarda leptin düzeyinin artabileceği, erkeklerde azalabileceği ve puberteyle beraber vücut yağ oranı ve VKI'deki değișikliklerinde etkili olacağ 1 düşünülebilir (19).

\section{KAYNAKLAR}

1. Kalyoncu AF,Demir AU,Özçakar B,Bozkurt B,Artvinli M. Asthma and allergy in Turkish university students:Two cross-sectional surveys 5 years apart .Allergol Immunopathol 2001;29:264-71

2. Viinanen A, Munhbayarlah S,Zevgee T,Narantsetseg L, Naidansuren TS, Koskenvuo M,Helenius H, Terho EO. Prevalence os asthma, allergic rhinoconjunctivitis and allergic sensitization in Mongolia. Allergy 2005;60:1370-7

3. Ford ES. The epidemiology of obesity and asthma. J Allergy Clin Immunol 2005;115:897-909.

4. Shore SA. Obesity and asthma: possible mechanisms. J Allergy Clin Immunol 2008;121:1087-1093.

5. Litonjua AA, Gold DR .Asthma and obesity: common early-life influences in the inception of disease. J Allergy Clin Immunol 2008; 121:10751084

6. Van Veen IH, Ten Brinke A, Sterk PJ, Rabe KF, Bel $\mathrm{EH}$. Airway inflammationin obese and nonobese patients with difficult-to-treat asthma. Allergy 2008; 63:570-574.

7. Husemoen LL, Glumer C, Lau C, Pisinger C, Morch LS, Linneberg A . Association of obesity and insulin resistance with asthma and aeroallergen sensitization. Allergy 2008; 63:575-582.

8. Marcos L, Arnedo Pena A, Busquets-Monge R, Morales Sua'rez-Varela M, Garci'a de Andoin N, Batlles- Garrido $\mathrm{J}$ et al. How the presence ofrhinoconjunctivitis and the severity of asthma modify the relationship betweenobesity and asthma in children 6-7 years old. Clin Exp Allergy 2008; 38:1174-1178

9. Beuther DA, Weiss ST, Sutherland ER. Obesity and asthma. Am J Respir Crit Care Med 2006;174:112 9

10. Sutherland ER, Goleva E, Strand M, Beuther DA, Leung DY. Body mass and glucocorticoid response in asthma. Am J Respir Crit Care Med 2008;178:682-7.
11. Rosenbaum M, Nicolson M, Hirsch J, Heymsfield SB, Gallagher D, Chu F, et al. Effects of gender, body composition, and menopause on plasma concentrations of leptin. J Clin Endocrinol Metab1996;81:3424-7.

12. Meyer K, Rajesk K, Gordon R, Herman E, Agustin C, Peter J, Carolyn M, Cynthia M, Elizabeth C, Suzanna F, Stanley J, Christine A, Wayne JM . Asthma control, adiposity, and adipokines among iner-city adolescents. Asthma \& Immunology.2010;584-92.

13. Jartti T, Saarikoski L, Jartti L, Lisinen I, Jula A, Huupponen R, Viikari J, Raitakari OT. Obesity, adipokines and asthma Allergy 2009;64:770-777

14. Guler N, Kirerleri E, Ones U, Tamay Z, Salmayenli $N$, Darendeliler F. Leptin: does it have any role in childhood asthma? J Allergy ClinImmunol 2004;114: 254-259.

15. Mai XM, Bottcher MF, Leijon I. Leptin and asthma in overweight children at 12 years of age. Pediatr Allergy Immunol 2004;15: 523-30.

16. D.Rothenbacher, M.Weyerman, G.Fantuzzi, H Brenner .Adipokines in cord blood and risk of wheezing disorders within the first two years of life. Clnical and Experimental Allergy 2007;37:1143-49

17. Shore SA, Terry RD, Flynt L, Xu A, Hug C. Adiponectin attenuates allergen-induced airway inflammation and hyperresponsiveness in mice. $\mathrm{J}$ Allergy Clin Immunol 2006;118: 389-95.

18. Herbert Tilg and Alexander R. Moschen Nature Reviews Immunology 2006; 6:772-783.

19. Blum WF, Englaro P, Hanitsch S, Juul A, Hertel NT, Müller J. Plasma leptin levels in healty children and adolescent: dependence on body mass index, body fat mass, gender, pubertal stage and testosterone. J.Clin Endocrinol Metab 1997;82:2904-10 